\title{
Association Study of Single Nucleotide Polymorphism in Exon 3 of SPAG11B Gene with Conception Rate in Murrah Bulls
}

\author{
Bharti Deshmukh $^{1 *}$, Archana Verma ${ }^{2}$, Ishwar Dayal Gupta ${ }^{2}$, \\ Neeraj Kashyap ${ }^{3}$ and Rajalaxmi Behera ${ }^{4}$ \\ ${ }^{1}$ Department of Veterinary and Animal Husbandry Extension Education, Guru Angad Dev \\ Veterinary and Animal Sciences University, Ludhiana, India \\ ${ }^{2}$ Division of Animal Genetics and Breeding, ICAR-National Dairy Research Institute, \\ Karnal, India \\ ${ }^{3}$ Department of Animal Genetics and Breeding, Guru Angad Dev Veterinary and Animal \\ Sciences University, Ludhiana, India \\ ${ }^{4}$ ICAR-National Dairy Research Institute, Eastern Research Station, Kalyani, Kolkata, India \\ *Corresponding author
}

\begin{abstract}
A B S T R A C T
Present study was conducted with the objectives to identify single nucleotide polymorphism in sperm associated antigen $11 \mathrm{~B}($ SPAG11B) gene and to analyze association between identified polymorphism with conception rate in Murrah bulls in ICAR-National Dairy Research Institute (NDRI) herd, Karnal. A 373 base pair region covering partial intron 2, exon 3 and partial intron3 of bovine SPAG11 gene was amplified using genomic DNA extracted from eighty six Murrah bulls and genotyped using sequencing and polymerase chain reaction- restriction fragment length polymorphisms (PCR-RFLP) methods. Alignment of edited sequence of Murrah buffalo with reported Bos taurus sequence (AC_000158.1) was done with ClustalW analysis. Gene and genotype frequencies, effective allele number, average heterozygosity and polymorphic information content of different genotypes were estimated by POPGENE version 1.32 (University of Alberta, Canada). Statistical analysis for Conception rate of Murrah bulls under study was carried out by SAS Version 9.3(SAS Institute Inc., Cary, NC, USA). The 373 bp fragment of SPAG11 gene was amplified using PCR and a novel SNP of G to A substitution at 2266 base of the SPAG11B gene was identified by sequencing. The amplicon was further digested with SNP-specific MunI restriction enzyme that showed three distinct genotypes viz., AA (266 bp and 107 bp fragment), GA (307 bp, 266 bp and $107 \mathrm{bp}$ ) and GG (373 bp fragment). Least square means of conception rate for the SNP was estimated and compared after correction for non-genetic factors. The identified novel SNP of SPAG11 gene showed nonsignificant association with conception rate. However, there is a lack of association, further studies have to be undertaken in a large population in order to validate the impact of g.2266G>A on conception rate in Murrah bulls.
\end{abstract}

\section{Introduction}

Buffalo is the principal dairy animal in the developing Asian countries and is the mainstay of the Indian dairy industry. India resides world's largest buffalo population as 108.7 million. In India, the buffalo population currently producing 70.44 million tons of milk, contributes 51.16 percent of the total milk despite they account for only 36.28 percent of total bovine population (Anonymous, 2015). India is the native tract of the world's premium buffalo breeds, although a huge scope of further improvement in productivity still remains. A higher selection intensity for faster genetic growth 
and success of AI technique calls for lesser bulls to cover a large breed able population, increasing the impact of bull fertility on overall reproductive performance. Continuous improvement of productivity demands higher availability of superior bulls with high genetic merit and fertility together (Lucy, 2001). An important indicator of fertility is conception rate $(\mathrm{CR})$, which is defined as the percentage of females diagnosed as pregnant by conventional means (rectal palpation, ultrasonography, hormonal assay) at some specified interval after AI (e.g. 60 days).

Progress in molecular genetic techniques has enabled the application of DNA polymorphism as an aid to the selection of animals through what is known as markerassisted selection (MAS). Recently, many reports regarding the use of the candidate gene as a marker for semen quality from swine (Huang et al., 2002; Wimmers et al., 2005; Lin et al., 2006) and goats (Wang et al., 2011a) have been conducted. However, few studies have reported on candidate marker genes in cow bulls (Dai et al., 2009; Yang et al., 2011; Gorbani et al., 2009a, b) and rare studies performed in buffalo bulls.

There are a number of candidate genes associated with sperm quality of which Sperm Associated Antigen 11 (SPAG11) gene requires special attention. SPAG11 (family $\beta$ defensin) is a gene which encodes several androgen-dependent, epididymis-specific secretary proteins which are involved in sperm maturation, acquiring motility, capacitation, and sperm-egg interaction. In cattle, the sperm-associated antigen 11 (SPAG11) gene is placed in $\beta$-defensins cluster and is a unique member among the human and bovine $\beta$ defensins due to its complex genomic organization and mRNA splicing pattern (Schutte et al., 2002; Avellar et al., 2007). The SPAG11 gene, also known as epididymal protein 2 (EP2) in monkeys, human epididymis 2 (HE2) in humans, and Bin-1b in rats, performs both immune and reproductive functions in humans (Yenugu et al., 2006), rats (Li et al., 2001; Zhou et al., 2004) and cattle (Avellar et al., 2007). Avellar et al., (2007) showed that in adult bulls, SPAG11C, SPAG11E, and SPAG11U mRNA are predominantly located in the male reproductive tract, whereas SPAG11V and SPAG11W are confined to testicular tissues. Also, SPAG11 plays a critical role in sperm maturation such as in the development of sperm motility (Zhou et al., 2004), a possible role in spermatogenesis, and in antimicrobial protection during sperm passage through the male and female tracts (Yenugu et al., 2006). As semen quality traits are crucial factors affecting conception rate for bulls; the SPAG11 gene appears to be a good candidate for mutations associated with bull's reproductive performance. The current study was undertaken to identify SNPs in SPAG11 gene which affects bull fertility in Murrah bulls that can be incorporated into the future buffalo breeding programs in India.

\section{Materials and Methods}

\section{Ethical approval}

The present experiment was approved by the Institutional Animal Ethics Committee of the ICAR-National Dairy Research Institute, Karnal, Haryana.

\section{Place of study and resource population}

The geographical location of N.D.R.I. Livestock Farm is at an altitude of 250 meters above the mean sea level in the Indo-Gangetic alluvial plains on $29.68^{\circ} \mathrm{N}$ latitude and $76.98^{\circ} \mathrm{E}$ longitude. The climate of the farm is subtropical in nature. Each year was subclassified into four major seasons viz., winter (December to March), summer (April to June), rainy (July to September), and autumn 
(October to November), depending on prevalent meteorological factors as recorded in Central Soil Salinity Research Institute, Karnal (Singh, 1983). The animals in the study consisted of total86 Murrah bulls having semen samples and records of AI maintained at Artificial Breeding Research Centre, ICARNational Dairy Research Institute, Karnal, India.

\section{Genotyping of SNP}

Genomic DNA was isolated from frozen semen samples of all the bulls using phenolchloroform extraction method with an addition of $25 \mu \mathrm{l}$ of $1 \mathrm{M}$ DTT $/ \mathrm{ml}$ of semen prior to addition of proteinase K. Primers 5'GGCAGTTTCTTGGGGTCAAT -3' (Forward) and 5'- GCACATCG CAGG TGCTTATT -3' (Reverse) were used for the PCR reaction for amplifying the 373 base pair covering partial intron 2, exon 3 and partial intron 3 region of bovine SPAG11 gene (Figure 1). The PCR reaction was carried out in a final volume of $25 \mu 1$ reaction mixture containing $12.5 \mu \mathrm{l}$ of Dream $\mathrm{Taq}^{\mathrm{TM}}$ Green PCR Master Mix (Fermentas, Life Sciences, USA), $9.5 \mu \mathrm{L}$ nuclease free water and $1 \mu 1$ each of template DNA, forward and reverse primers $(10 \mathrm{pmol} / \mu \mathrm{l})$. PCR reaction profile consisted of initial denaturation at $95^{\circ} \mathrm{C}$ for $3 \mathrm{~min}$, followed by 40repeated cycles of denaturation at $95^{\circ}$ for $30 \mathrm{sec}$, annealing at $62^{\circ} \mathrm{C}$ for $35 \mathrm{sec}$ and extension at $72^{\circ} \mathrm{C}$ for 1 min followed by final extension for $5 \mathrm{~min}$ at $72^{\circ} \mathrm{C}$. Twenty amplicons were sequenced and aligned by ClustalW for identification of the SNPs and then it was subjected to restriction enzyme (RE) digestion. For PCR-RFLP analysis, amplified PCR products of exon 3 was digested with site specific MunI enzyme (Thermo Scientific, USA). The digestion was done in a final volume of $25 \mu \mathrm{L}$ containing 0.5 $\mu \mathrm{L}(5 \mathrm{U} / \mu \mathrm{L})$ restriction enzyme, $2.0 \mu \mathrm{L}$ buffer, $12.5 \mu \mathrm{L}$ nuclease free water and $10 \mu \mathrm{L}$ PCR product, incubated in $37{ }^{\circ} \mathrm{C}$ for $10-12 \mathrm{hrs}$.
Separation of digested products was done by 2.5-3\% agarose gel (with added ethidium bromide at $2 \mu \mathrm{L} / 100 \mathrm{~mL}$ ) horizontal electrophoresis and visualized with the help of gel doc system (Bio-Rad).

\section{Recording of data}

The complete AI records of total 86 Murrah bulls under study for a period of 35 years (1980 to 2014) and its success was obtained from records of reproductive history cum pedigree sheets maintained at Livestock Record Unit of Dairy Cattle Breeding Division, ICAR-National Dairy Research Institute, Karnal, India. The records were used for estimation of conception rate for Murrah bulls.

\section{Statistical analysis and association study}

The genetic polymorphism parameters like gene and genotype frequencies, effective number of alleles, average heterozygosity and polymorphism information content of different genotypes were estimated using POPGENE (version 1.32) software.

For the statistical analysis of the conception rate; the SAS package (Version 9.3) was used. Non-genetic factors (NGF) were classified into subgroups as per Table 1, analyzed for effects of NGF on conception rate in Murrah bulls and then data were adjusted for the significant NGF i.e. season and period of AI using least square constants. Corrected data were considered as dependent variable whereas genotypes of the animals were taken as independent variables for the analysis of effect of genotypes. Following model was used for the analysis of effects of genotypes; $Y_{l m}=\mu+G_{l}+e_{l m}$ where, $Y_{l m}$ is the corrected observation of $\mathrm{m}^{\text {th }}$ bull having $1^{\text {th }}$ genotype, $\mu$ is the overall mean, $G_{1}$ is the fixed effect of $l^{\text {th }}$ genotype and $\mathrm{e}_{\mathrm{lm}}$ is the random error. 


\section{Results and Discussion}

The bovine SPAG11 gene is located on chromosome 27q1.2 and is composed of six exons (3 coding exons) and five introns, spanning about $34 \mathrm{~kb}$. Recent studies conducted on cattle semen confirm that several sperm surface proteins can be used as markers for male fertility (Moura et al., 2006), and SPAG11 is one of them. Thus the polymorphisms in this gene contain potential as candidates for the male fertility.

Total five nucleotide changes ( 3 transversion and 2 transition) and a deletion of $22 \mathrm{bp}$ segment were found when sequence of Murrah buffalo was compared with Bos taurus and one SNP (g.2266G>A) in exon 3 was detected from 20samplesthrough direct sequencing and ClustalW alignment of the sequences. For SNP g.2266G>A, a site specific restriction enzyme MunI was identified. In Murrah bulls, the 373 bp fragment of SPAG11 upon restriction digestion, yielded three distinct genotypes viz., AA (266 bp and 107 bp fragment), GA (307 bp, $266 \mathrm{bp}$ and $107 \mathrm{bp}$ ) and GG (373 bp fragment) (Figure 2). The SNP found was novel and no homologous SNP for this site was reported in buffalo or cattle. However 6 SNPs have been reported in exonic region of SPAG11 gene in Chinese Holstein bulls by Liu et al., (2011) as 3 completely linked groups.

The genotype frequencies for genotype AA, GA and GG were $0.2847,0.4615$ and 0.2538 , respectively and gene frequencies of allele $\mathrm{A}$ and $\mathrm{G}$ were 0.5154 and 0.4846 , respectively in the Murrah bulls. Allele A was marginally predominant in the present population and the difference in the genotype frequencies might be due to selection in the Murrah bulls. The population under study was found to be in Hardy Weinberg equilibrium $(p<0.05)$ with respect to this SNP indicating that there was negligible selection pressure on the locus. The effective number of allele, Shannon's index, average heterozygosity, PIC and $\chi^{2}$ values for the locus g: $2266 \mathrm{G}>\mathrm{A}$ were found to be $1.9981,0.6927,0.5015,0.3748$ and 0.8301 respectively. Polymorphic information content (PIC) for this genetic variant was found to be $<0.5$ indicating that the locus is moderately polymorphic in Murrah herd.

A number of possible interpretations support the speculation that genetic variations in the SPAG11 gene of the buffalo bulls may be important for fertility. Numerous studies found isoforms of SPAG11 performing both immune and reproductive functions in species like rats (Li et al., 2001), humans (Zhou et al., 2004) and cattle (Avellar et al., 2007). Specific affinity of SPAG11 isoforms in mRNA expression to majorly or exclusively in male reproductive tract (Avellar et al., 2007) is in support to the suggestion. Further, SPAG11 plays a critical role in the development of sperm motility (Zhou et al., 2004), spermatogenesis and antimicrobial protection of spermatozoa (Yenugu et al., 2006).

In the present study, 5439 AI records of 86 Murrah bulls spanning over 35 years with season, period, parity and female AI number as NGFs, were utilized for calculation of conception rate per bull. The genotypes AA and $A G$ have higher mean conception rate as compared to genotype GG but the differences were not significant. Effect of the locus (g.2266G>A) on conception rate of 86Murrah bulls are summarized in Table 2. The results of association study for the locus were confirmed by chi-square analysis with respect to distribution of animals in different fertility groups viz. high, medium and low with conception rate $>42 \%, 35-42 \%$ and $<35 \%$, respectively. Animals with GA genotype were fewer in low fertility group whereas animals with genotype GG were found least in high fertility groups (Table 3). 
Table.1 Classification of non-genetic factors (season of AI, periods of AI, parity and female A.I. no) for conception rate in Murrah bulls

\begin{tabular}{|l|l|l|l|l|}
\hline S. No. & Season of AI & Period & Parity & Female AI no \\
\hline $\mathbf{1}$ & Summer (Apr-Jun) & $1980-1996$ & First & First AI after calving \\
\hline $\mathbf{2}$ & Rainy (Jul-Sept) & $1997-2002$ & Second & Second AI after calving \\
\hline $\mathbf{3}$ & Autumn (Oct-Nov) & $2003-2008$ & Third & Third AI after calving \\
\hline $\mathbf{4}$ & Winter (Dec-Mar) & $2009-2014$ & Fourth & Fourth AI after calving \\
\hline $\mathbf{5}$ & - & - & Fifth and above & Fifth and more AI after calving \\
\hline
\end{tabular}

Table.2 ANOVA of conception rate for genotypes of SPAG11 gene

\begin{tabular}{|l|l|l|l|l|}
\hline Source & Degree of Freedom & Sum of Squares & Mean Sum of Square & F value \\
\hline 289 G>A & 2 & 48.69 & 24.34 & 0.78 \\
\hline
\end{tabular}

Table.3 Least square means \pm S.E. of conception rate for genotypes of SPAG11 gene

\begin{tabular}{|l|l|l|l|}
\hline Locus & Genotypes & No. of bulls & CR \\
\hline $\mathbf{2 8 9} \mathbf{G}>\mathbf{A}$ & AA & 25 & $39.85 \pm 1.85$ \\
\hline & GA & 41 & $38.60 \pm 1.44$ \\
\hline & GG & 20 & $36.32 \pm 2.06$ \\
\hline
\end{tabular}

Table.4 Chi-square analysis of genetic variants of SPAG11 gene and bull fertility level in Murrah bulls

\begin{tabular}{|c|c|c|c|c|c|c|c|c|c|c|}
\hline \multirow[t]{2}{*}{ SNP } & \multirow[t]{2}{*}{ Genotype } & \multicolumn{6}{|c|}{ Fertility levels } & Total & \multirow{2}{*}{$\begin{array}{l}\chi^{2} \\
\text { value }\end{array}$} & \multirow{2}{*}{$\begin{array}{l}\mathbf{P} \\
\text { Value }\end{array}$} \\
\hline & & \multicolumn{2}{|c|}{ High $>42 \%$} & \multicolumn{2}{|c|}{ Medium 35-42\% } & \multicolumn{2}{|c|}{ Low $<35 \%$} & & & \\
\hline \multirow{3}{*}{$\begin{array}{l}289 \\
G>A\end{array}$} & AA & 9 & 10.47 & 8 & 9.30 & 8 & 9.30 & 25 & \multirow[t]{3}{*}{2.21} & \multirow[t]{3}{*}{0.70} \\
\hline & GA & 15 & 17.44 & 15 & 17.44 & 11 & 12.79 & 41 & & \\
\hline & GG & 4 & 4.65 & 8 & 9.30 & 8 & 9.30 & 20 & & \\
\hline
\end{tabular}

Fig.1 PCR amplification of 373 base pair fragment covering partial intron 2, exon 3 and partial intron 3 region of SPAG11 gene in Murrah Buffalo

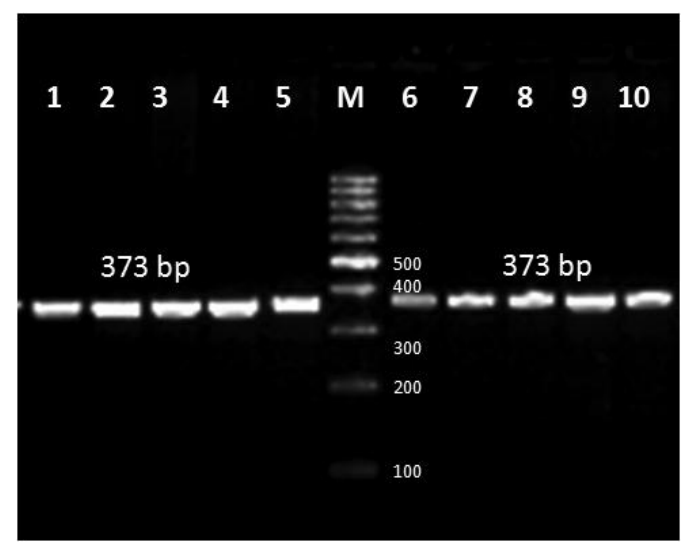


Fig.2 PCR-RFLP of 373 base pair fragment of SPAG11 gene in Murrah Buffalo

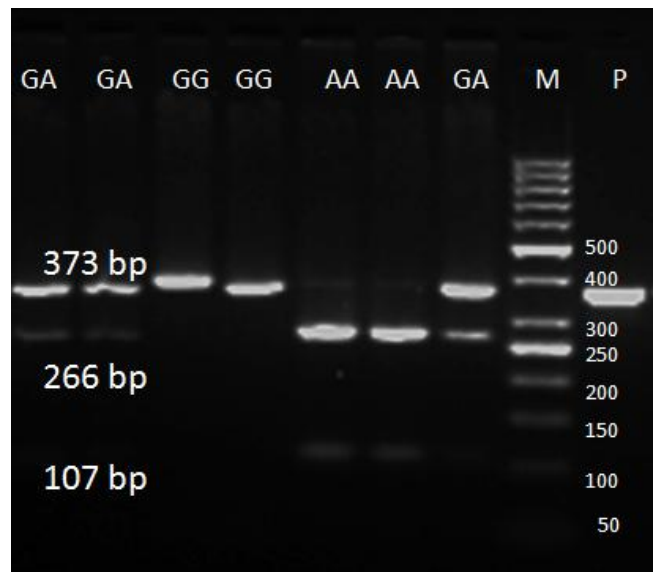

However $\chi^{2}$ analysis indicated that the genotypes and fertility groups were statistically independent (Table 4).

Till date, no any report on association of SNPs in SPAG11 gene with conception rate in Murrah bulls to compare and contrast with the findings of present study. Therefore, findings of the present study are compared with the available sporadic reports on cattle. Out of the six SNPs of Bovine SPAG11 gene identified by Liu et al., (2011),two SNPs were significantly correlated with the sperm quality traits i.e. sperm concentrations and fresh sperm motility while one SNP was significantly correlated with post-thaw sperm motility and percentage of abnormal spermatozoa $(\mathrm{P}<0.01)$. However the SNPs were identified in Chinese Holstein Cattle and were non-homologous to the SNPs identified in Murrah bulls. Thus even if the SNPs detected in the exon 3 of SPAG11 gene show no statistical relation to conception rate in Murrah bulls, considering the importance of the gene, further exploration of the whole gene for identification of SNPs affecting fertility is called for, to ensure betterment of male fertility in Murrah bulls.

The selection of the SPAG11 polymorphism in a breeding program may improve male fertility that may further result in higher success rate of Artificial Inseminations leading to better reproductive efficiency of the herd. Statistical analysis yielded no significant association between the genotypes with conception rate. Although, there is lack of association, further studies are required to investigate more such polymorphisms and to understand the complex genetic mechanisms of bull fertility traits in a larger number of buffalo bulls.

\section{References}

Anonymous, 2015. Basic Animal Husbandry \& Fisheries Statistics-2015, Department of Animal Husbandry, Dairying and Fisheries, Ministry of Agriculture, Government of India.

Avellar, M.C.W., Honda, L., Hamil, K.G., Radhakrishnan, Y., Yenugu, S., Grossman, G., Petrusz, P., French, F.S., and Hall, S.H., 2007. Novel aspects of the sperm-associated antigen 11 (SPAG11) gene organization and expression in cattle (Bos taurus). Biol. Reprod. 76, 1103-1116.

Dai, L., Zhao, Z., Zhao, R., Xiao, S., Jiang, H., Yue, X., Li, X., Gao, Y., Liu, J., and Zhang, J., 2009. Effects of novel single nucleotide polymorphisms of the FSH $\beta$-subunit gene on semen quality and fertility in bulls. Anim. Reprod. Sci. 114, 14-22.

Gorbani, A., Vaez Torshizi, R., Bonyadi, M., and Amirinia, C., 2009a. Restriction fragment 
length polymorphism of bovine growth hormone gene intron 3 and its association with testis biometry traits in Iranian Holstein bull. Afr. J. Microbiol. Res. 3, 809-814.

Gorbani, A., Vaez Torshizi, R., Bonyadi, M., and Amirinia, C., 2009b. A MspI PCR-RFLP within bovine growth hormone gene and its association with sperm quality traits in Iranian Holstein bulls. Afr. J. Biotechnol. 8, 4811-4816.

Huang, S.Y., Chen, M.Y., Lin, E.C., Tsou, H.L., Kuo, Y.H., Ju, C.C., and Lee, W.C., 2002. Effects of single nucleotide polymorphisms in the 5 -flanking region of heat shock protein 70.2 gene on semen quality in boars. Anim. Reprod. Sci. 70, 99-109.

Li, P., Chan, H.C., He, B., So, S.C., Chung, Y.W., Shang, Q., Zhang, Y.D., and Zhang, Y.L., 2001. An antimicrobial peptide gene found in the male reproductive system of rats. Science 291, 1783-1785.

Lin, C.L., Ponsuksili, S., Tholen, E., Jennen, D.G., Schellander, K., and Wimmers, K., 2006. Candidate gene markers for sperm quality and fertility of boar. Anim. Reprod. Sci. 92, 349-363.

Liu, X., Ju, Z., Wang, L., Zhang, Y., Huang, J., Li, Q., Li, J., Zhong, J., An, L., and Wang, C., 2011. Six novel single nucleotide polymorphisms in SPAG11 gene and their association with sperm quality traits in Chinese Holstein bulls. Anim. Reprod. Sci., 129: $14-21$.

Lucy, M.C., 2001. Reproductive loss in highproducing dairy cattle: where will it end? Journal of Dairy Science, 84(6): 1277-1293.

Moura, A.A., Koc, H., Chapman, D.A., and Killian, G.J., 2006. Identification of proteins in the accessory sex gland fluid associated with fertility indexes of dairy bulls: a proteomic approach. J. Androl. 27, 201-211. Schutte, B.C., Mitros, J.P., Bartlett, J.A., Walters, J.D., Jia, H.P., Welsh, M.J., Casavant, T.L., and McCray Jr., P.B., 2002. Discovery of five conserved betadefensin gene clusters using a computational search strategy. Proc. Natl. Acad. Sci. U.S.A. 99, 2129-2133.

Wang, C.F., Liu, M., Li, Q.L., Ju, Z.H., Huang, J.M., Li, J.B., and Zhong, J.F., 2011. Three novel single-nucleotide polymorphisms of MBL1 gene in Chinese native cattle and their associations with milk performance traits. Vet. Immunol. Immunopathol. 139, 229-236.

Wimmers, K., Lin, C.L., Tholen, E., Jennen, D.G., Schellander, K., and Ponsuksili, S., 2005. Polymorphisms in candidate genes as markers for sperm quality and boar fertility. Anim. Genet. 36, 152-155.

Yang, W.C., Tang, K.Q., Yu, J.N., Zhang, C.Y., Zhang, X.X., and Yang, L.G., 2011. Effects of MboII and BspMI polymorphisms in the gonadotropin releasing hormone receptor (GnRHR) gene on sperm quality in Holstein bulls. Mol. Biol. Rep. 38, 3411-3415.

Yenugu, S., Hamil, K.G., Grossman, G., Petrusz, P., French, F.S., and Hall, S.H., 2006. Identification, cloning and functional characterization of novel sperm associated antigen 11 (SPAG11) isoforms in the rat. Reprod. Biol. Endocrinol. 4, 23.

Zhou, C.X., Zhang, Y.L., Xiao, L., Zheng, M., Leung, K.M., Chan, M.Y., Lo, P.S., Tsang, L.L., Wong, H.Y., Ho, L.S., Chung, Y.W., and Chan, H.C., 2004. An epididymis specific $\beta$-defensin is important for the initiation of sperm maturation. Nat. Cell Biol. 6, 458-464.

\section{How to cite this article:}

Bharti Deshmukh, Archana Verma, Ishwar Dayal Gupta, Neeraj Kashyap and Rajalaxmi Behera. 2019. Association Study of Single Nucleotide Polymorphism in Exon 3 of SPAG11B Gene with Conception Rate in Murrah Bulls. Int.J.Curr.Microbiol.App.Sci. 8(08): 1535-1541. doi: https://doi.org/10.20546/ijcmas.2019.808.180 